\title{
PERBANDINGAN IBU MEMBERIKAN ASI EKSKLUSIF DAN NON ASIEKSKLUSIF TERHADAP AMENOREA LAKTASI
}

\author{
KrisnaDelita $^{1}$, Ahmad Arif ${ }^{1}$, GethyWirananti ${ }^{2}$, Hajiawati ${ }^{2}$ dan Indah Yunita ${ }^{2}$ \\ Program Studi Diploma IV KebidananUniversitas Kader Bangsa Palembang \\ Jl. Mayjend H.M. Ryacudu No. 88 Palembang Sumatera Selatan, Indonesia \\ Email :krisnadelita30@gmail.com
}

\begin{abstract}
Abstrak
ASI Eksklusif adalah pemberian ASI pada bayi sampai usia 6 bulan tanpa tambahan makanan apapun. ASI eksklusif merupakan cara sempurna untuk memberikan makanan terbaik pada masa enam bulan pertama kehidupan bayi. Selain dapat mempererat hubungan antara ibu dan bayi, ASI dapat dijadikan sebagai alat kontrasepsi yang dikenal dengan Metode Amenorea Laktasi (MAL). Penelitian ini bertujuan untuk mengetahui perbandingan antara ibu yang memberikan ASI Eksklusif dan non ASI Eksklusif terhadap amenorea laktasi di Wilayah Kerja UPTD Puskesmas Tanjung Agung Baturaja. Metode penelitianmenggunakan penelitian komparatif dengan pendekatan cross sectional. Teknik pengambilan sampel menggunakan accidental sampling. Jumlah sampel adalah 52 ibu yang mempunyai bayi usia 6-12 bulan yang memberikan ASI kepada bayinya di wilayah kerja UPTD Puskesmas Tanjung Agung Baturaja yang ada pada saat penelitian berlangsung. Pengumpulan data dilakukan dengan teknik wawancara menggunakan kuesioner. Hasil analisis univariat didapatkan bahwa responden yang memberikan ASI Eksklusif berjumlah 28 responden $(53,8 \%)$ dan sebanyak 25 responden (89,2\%) merupakan MAL. Dari 24 responden (46,2\%) yang tidak memberikan ASI Eksklusif, hanya 2 responden (8,3\%) yang menjadi pengguna MAL. Hasil analisis bivariat dengan menggunakan uji-T menunjukkan ada perbedaan yang signifikanantara ibu yang memberikan ASI Eksklusif dan Non ASI Eksklusif terhadap Amenorea Laktasi dengan nilai Sig. (2-tailed) sebesar 0,000 .
\end{abstract}

Kata Kunci :ASI EksklusifdanAmenoreaLaktasi

\begin{abstract}
Exclusive breastfeeding is breastfeeding for infants up to 6 months of age without any additional food. Exclusive breastfeeding is the perfect way to provide the best food during the first six months of a baby's life. Besides being able to strengthen the relationship between mother and baby, breast milk can be used as a contraception known as the Amenorrhea Lactation Method (MAL). This study aims to determine the comparison between mothers who give exclusive and non-exclusive breastfeeding to lactation amenorrhea at working area of UPTD Tanjung Agung Baturaja Health Center. The research method uses comparative research with a cross sectional approach. The sampling technique uses accidental sampling. The number of samples is 52 mothers who have babies aged 6-12 months who give breast milk to their babies in the working area of UPTD Tanjung Agung Baturaja Health Center that existed at the time of the study. Data collection is done by interviewing techniques using questionnaires. The results of univariate analysis found that respondents who gave exclusive breastfeeding amounted to 28 respondents (53.8\%) and as many as 25 respondents (89.2\%) were MAL. Of the 24 respondents (46.2\%) who did not provide exclusive breastfeeding, only 2 respondents $(8.3 \%)$ became MAL users. The results of bivariate analysis using the T-test showed that there were significant differences between mothers who gave exclusive and non-exclusive breastfeeding to Amenorrhea Lactation with Sig. (2-tailed) of 0,000.
\end{abstract}

Key words: Exclusive breastfeedingandamenorrhea lactation 


\section{PENDAHULUAN}

Indonesia merupakan salah satu negara yang memiliki jumlah penduduk terbesar di dunia setelah berturut-turut China, India dan Amerika Serikat. Masalah utama yang sedang dihadapi negara-negara berkembang termasuk Indonesia adalah masih tingginya laju pertumbuhan penduduk dan kurang seimbangnya penyebaran dan struktur umur penduduk. Keadaan penduduk yang demikian telah mempersulit usaha meningkatkan dan pemerataan kesejahteraan rakyat.

Salah satu upaya pemerintah untuk mengendalikan laju pertumbuhan penduduk adalah melalui pelaksanaan program Keluarga Berencana (KB). KBmenurut UU Nomor 52 Tahun 2009 (tentang perkembangan kependudukandan pembangunan keluarga) adalah upaya merencanakan perkawinan, mengatur kelahiran anak, jarak dan usia ideal melahirkan, mengatur kehamilan melalui promosi, perlindungan, dan bantuan sesuai dengan hak reproduksi untuk mewujudkan keluarga yang berkualitas (Malinda, Suprapti, danKusumawati 2013).

BKKBN telah mensosialisasikan berbagai metode kontrasepsi. Seiring dengan berkembangnya teknologi, kontrasepsi dibuat bervariasi dan disertai beragam tujuan penggunaannya. Untuk memenuhi kebutuhan kontrasepsi yang efektif dan aman pada periode postnatal, pemerintah telah mensosialisasikan metode kontrasepsi LAM (Lactation Amenorrhea Method) (Suparmi, 2010).

Metode Amenorea Laktasi (MAL) adalah kontrasepsi yang mengandalkan pemberian Air Susu Ibu (ASI) secara eksklusif, artinya hanya diberikan ASI tanpa tambahan makanan dan minuman apapun lainnya (Saifuddin, 2006). MAL dipandang sebagai salah satu KB alamiah dengan memberikan ASI Eksklusif yang dapat digunakan sebagai kontrasepsi transisi, maka pemerintah mengeluarkan dukungan mengenai ASI Eksklusif ditunjukkan dengan Kepmenkes RI No.450/MENKES/IV/2004 tentang pemberian Air Susu Ibu (ASI) secara eksklusif bagi bayi Indonesia dan dianjurkan dilanjutkan sampai usia 2 tahun dengan MPASI (Depkes 2010, dalam Nazriyanti dan Rosida 2017:4).

Penerapan MALdi Indonesia masih rendah, hal ini diukur dari rendahnya tingkat pencapaian pemberian ASI Eksklusif (Muryanto 2012, dalam Birrulwalalidaini dan Suratini 2016:2). Data dari Profil Kesehatan Indonesia (2017) menunjukkan cakupan bayi yang mendapat ASI Eksklusif sebesar $61,33 \%$. Dengan persentase tertinggi cakupan pemberian ASI Eksklusif terdapat pada Nusa Tenggara Barat $(87,35 \%)$, dan persentase terendah terdapat pada Papua (15,32\%). Sedangkan untuk Provinsi Sumatera Selatan sendiri cakupannya sebesar 60,36\%.

Berdasarkan Profil Kesehatan Kabupaten Ogan Komering Ulu tahun 2018, cakupan pemberian ASI Eksklusif di wilayah Kabupaten Ogan Komering Ulu pada tahun 2017 yaitu sebesar $48,5 \%$ terjadi penurunan sebesar 2,7\% dari tahun 2016 (sebesar 51,2\%). Cakupan ini masih jauh dari target pencapaian pemberian ASI Eksklusif yaitu $80 \%$.

Data dari UPTD Puskesmas Tanjung Agung tahun 2018 terdapat sebanyak 181 bayi $(44,85 \%)$ yang telah mendapatkan ASI Eksklusif, hal ini mengalami peningkatan dari tahun sebelumnya yaitu sebanyak 154 bayi(38,17\%)yang telah diberikan ASI Eksklusif. Sedangkan data dari bulan Januari - Maret 2019, terdapat sebanyak 51 bayi(12,48\%)yang telah mendapatkan ASI Ekskusif.

Menurutpenelitianyang telahdilakukanoleh Djap Hadi Susanto, Rio Yansen, Andri Nugraha, danDea Mindy Sasmitadenganjudul "Hubungan antara ASI Eksklusif dengan Kejadian Amenore pada Ibu yang memiliki Bayi di Puskesmas Kelurahan Palmerah II Jakarta Barattahun 2017", didapatkan bahwa dari 110 responden, sebanyak $81 \quad(73,64 \%)$ memberikan ASI Eksklusif, 72responden $(88,9 \%)$ yang mengalami amenorea laktasi dan 9 responden $(11,1 \%)$ tidak mengalami amenorea laktasi. Sedangkan sebanyak 29 
(26,36\%) yang tidak memberikan ASI Eksklusif, dengan 24responden $(82,8 \%)$ tidak mengalami amenorea laktasi dan 5 respondenlainnya $(17,2 \%)$ mengalami amenorea laktasi. Dapat disimpulkan adanya hubungan secara bermakna antara ASI Eksklusif dengan kejadian amenorea $(\mathrm{p}=0,000)$.

Berdasarkan uraian diatas, maka peneliti tertarik untuk mengetahui lebih jauh mengenai "Perbandingan Antara Ibu yang Memberikan ASI Eksklusif dan Non ASI Eksklusif Terhadap Amenorea Laktasi di Wilayah Kerja UPTD Puskesmas Tanjung Agung Baturaja Tahun 2019”.

\section{METODE PENELITIAN}

Penelitian ini menggunakan penelitian komparatif yaitu penelitian yang dilakukan dengan cara membandingkan persamaan dan perbedaan sebagai fenomena untuk mencari faktor-faktor apa, atau situasi bagaimana yang menyebabkan timbulnya suatu peristiwa tertentu. Penelitian inimenggunakan pendekatan cross sectional,yaitu metode pengumpulan data, baik itu variabel dependen maupun variabel independen dilakukan secara bersama-sama atau sekaligus (Notoatmodjo,2010).Penelitiandilakukanpad abulan Mei - Juni 2019 di Wilayah Kerja UPTD

PuskesmasTanjungAgungBaturaja.Populasi dalam penelitian ini adalah semua ibu yang mempunyai bayi usia 6-12 bulan di wilayah kerja UPTD Puskesmas Tanjung Agung Baturaja.Teknik pengambilan sampel menggunakan accidental sampling, dengan jumlah sampel sebanyak 52 ibu yang mempunyai bayi usia 6-12 bulan yang memberikan ASI kepada bayinya di wilayah kerja UPTD Puskesmas Tanjung Agung Baturaja dan ada pada saat penelitian berlangsung.

Teknik pengumpulan data pada penelitian ini menggunakan data primer, yaitu data yang diperoleh langsung dari responden melalui pertemuan atau percakapanyang dipandu dengan kuesioner pada ibu-ibu yang mempunyai bayi usia 6-
12 bulan di wilayah kerja UPTD Puskesmas Tanjung Agung Baturaja. Responden mengisi informed consent yang telah disediakan oleh peneliti dan ebelumnya sudah diberikan penjelasan oleh peneliti tentang maksud tujuan penelitian serta tata cara pengisian kuesioner. Pada penelitian ini analisis data yang digunakan secara univariat, dan bivariat dengan uji Independent Sample T Test.

\section{HASIL PENELITIAN}

Tabel 1.Distribusi Frekuensi Responden Berdasarkan Kategori Pemberian ASI

\begin{tabular}{clcc}
\hline No. & $\begin{array}{c}\text { Pemberian } \\
\text { ASI }\end{array}$ & Frekuensi & Persentase \\
\hline 1 & ASI Ekskusif & 28 & 53,8 \\
2 & Non ASI & 24 & 46,2 \\
\hline & Eksklusif & 52 & 100 \\
\hline
\end{tabular}

Dari tabel di atas dapat diketahui bahwa jumlah responden yang memberikan ASI Eksklusif pada bayinya sebanyak 28 responden $(53,8 \%)$, sedangkan yang tidak memberikan ASI Eksklusif pada bayinya yaitu sebanyak 24 responden (46,2\%).

Tabel 2.Distribusi Frekuensi Responden Berdasarkan Kategori Amenorea Laktasi

\begin{tabular}{clcc}
\hline No. & Pemberian ASI & Frekuensi & Presentase \\
\hline 1 & MAL & 27 & 51,9 \\
2 & Tidak MAL & 25 & 48.1 \\
\hline & Jumlah & 54 & 100 \\
\hline
\end{tabular}

Berdasarkan tabel di atas dapat dilihat bahwa distribusi frekuensi responden yang merupakan MAL sebanyak 27 responden $(51,9 \%)$, sedangkan untuk yang tidak MAL yaitu 25 responden $(48,1 \%)$.

Tabel 3.Perbandingan antara Ibu yang Memberikan ASI Eksklusif dan Non ASI Eksklusif dengan Amenorea Laktasi

\begin{tabular}{ccccc}
\hline & \multicolumn{4}{c}{ Amenorea Laktasi } \\
Pemberian & \multicolumn{2}{c}{ MAL } & \multicolumn{2}{c}{ Tidak MAL } \\
\cline { 2 - 5 } ASI Eksklusif & f & $\%$ & f & \% \\
\hline ASI Eksklusif & 33 & 62.3 & 20 & 37.7
\end{tabular}




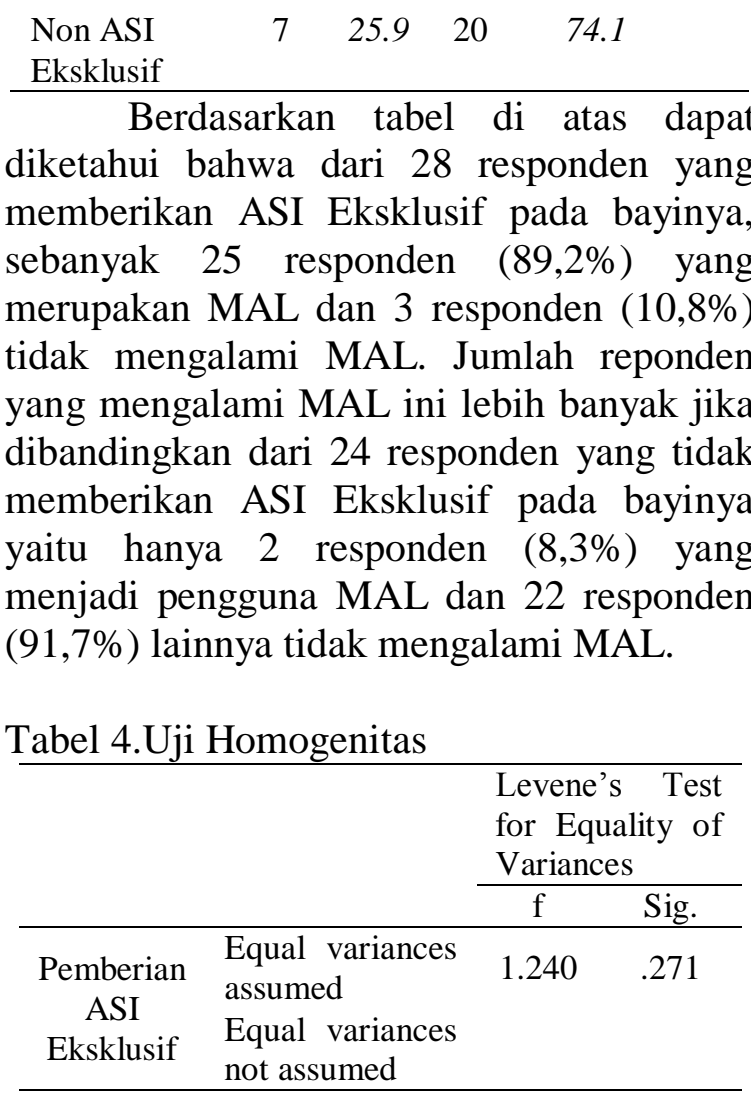

Dari data tabeldi atas dapat diliha nilai Sig. Levene's Test for Equality of Variances adalah 0,271 > 0,05 maka dapat diartikan bahwa varian data antara variabel Pemberian ASI Eksklusif adalah sama (homogen). Dengan demikian penafsiran tabel output Independent Samples Test di atas berpedoman pada nilai yang terdapat dalam tabel "Equal Variances Assumed".

Tabel 5.UjiIndependent Sample T Test

\begin{tabular}{|c|c|c|c|c|}
\hline & & \multicolumn{3}{|c|}{$\begin{array}{l}\text { Levene's Test } \\
\text { for Equality of } \\
\text { Variances }\end{array}$} \\
\hline & & $\mathrm{f}$ & Sig. & $\begin{array}{l}\text { Sig. (2- } \\
\text { tailed) }\end{array}$ \\
\hline Pemberian & $\begin{array}{l}\text { Equal } \\
\text { variances } \\
\text { assumed }\end{array}$ & -9.688 & 50 & .000 \\
\hline $\begin{array}{c}\text { ASI } \\
\text { Eksklusif }\end{array}$ & $\begin{array}{l}\text { Equal } \\
\text { variances } \\
\text { not } \\
\text { assumed }\end{array}$ & -9.607 & 46.107 & .000 \\
\hline
\end{tabular}

Dasar pengambilan keputusan dalam analisis uji $\mathrm{T}$ dapat dilakukan dengan dua cara, yang pertama yaitu dengan melihat signifikansi(Sig), dan yang kedua dengan membandingkan antara nilai $\mathrm{t}$ hitungdan $\mathrm{t}$ tabel.

Berdasarkan tabel di atas pada bagian Equal Variances Assumed diketahui nilai Sig. (2-tailed)sebesar $0,000<0,05$ maka sebagaimana dasar pengambilan keputusan dalam uji independent sample test dapat disimpulkan bahwa $\mathrm{HO}$ ditolak dan $\mathrm{Ha}$ diterima.

Kemudian diketahui untuk nilai $t$ hitung adalah sebesar 9,688. Selanjutnya mencari nilai $t$ tabel dengan mengacu pada rumus: (a/2); (df), maka didapatkan $(0,05 / 2)$; (50). Kemudian lihat nilai t 0,025 ; 50 pada distribusi nilai t tabel statistik, maka didapatkan nilai t tabel sebesar 2,009.

Dengan demikian nilai t hitung sebesar 9,688 > t tabel 2,009 maka berdasarkan dasar pengambilan keputusan melalui perbandingan nilai $t$ hitung dengan $t$ tabel, dapat disimpulkan bahwa $\mathrm{H}_{0}$ ditolak dan $\mathrm{H}_{\mathrm{a}}$ diterima.

Dengan demikian dari kedua dasar pengambilan keputusan di atas dapat disimpulkan bahwa ada perbedaan yang signifikan (nyata) antara ibu yang memberikan ASI Eksklusifdan Non ASI EksklusifterhadapAmenoreaLaktasi.

\section{PEMBAHASAN}

Berdasarkan hasil penelitian di atas dapat diketahui bahwa dari 28 responden yang memberikan ASI Eksklusif pada bayinya, sebanyak 25 responden $(89,2 \%)$ yang merupakan MAL dan sebanyak 3 responden $(10,8 \%)$ tidak mengalami MAL. Sedangkan dari 24 responden yang tidak memberikan ASI Eksklusif pada bayinya terdapat 2 responden $(8,3 \%)$ yang menjadi pengguna MAL dan 22 responden $(91,7 \%)$ lainnya tidak mengalami MAL.

Hasil uji statistik menggunakan Uji Indepentent Sample T Test, dengan nilai Sig. (2-tailed) sebesar $0,000<0,05$ sehingga dapat disimpulkan bahwa $\mathrm{H} 0$ ditolak dan $\mathrm{Ha}$ diterima. Dengan demikian dapat dinyatakan bahwa ada perbedaan yang signifikan (nyata) antara ibu yang memberikan ASI Eksklusif dan Non ASI Eksklusif terhadap 
Amenorea Laktasi di Wilayah Kerja UPTD Puskesmas Tanjung Agung Baturaja.

Hasil penelitian ini sejalan dengan penelitian yang telah dilakukan oleh Susanto, Yansen, Nugraha, dan Sasmita (2017) yang berjudul Hubungan antara ASI Eksklusif dengan Kejadian Amenore pada Ibu yang memiliki Bayi di Puskesmas Keluarahan Palmerah II Jakarta Barat. Dengan jumlah responden sebanyak 110 responden, diketahui sebanyak 81 responden $(73,64 \%)$ memberikan ASI Eksklusif, 72 responden $(88,9 \%)$ yang mengalami amenorea laktasi dan 9 responden $(11,1 \%)$ tidak mengalami amenorea laktasi. Sedangkan sebanyak 29 responden $(26,36 \%)$ yang tidak memberikan ASI Eksklusif dengan 24 responden $(82,8 \%)$ tidak mengalami amenorea laktasi dan 5 responden $(17,2 \%)$ mengalami amenorea laktasi. Dari hasil analisis bivariat didapatkan $(\mathrm{p}=0,000)$ sehingga disimpulkan adanya hubungan secara bermakna antara ASI Eksklusif dengan kejadian amenore laktasi.

ASI Eksklusif adalah pemberian ASI saja, termasuk kolostrum tanpa tambahan apapun sejak dari lahir, dengan kata lain pemberian susu formula, air matang, air gula, dan madu untuk bayi baru lahir tidak dibenarkan (Saleha, 2009).

ASI mempunyai komposisi yang lengkap bagi kebutuhan nutrisi bayi, oleh karena itu sebaiknya diberikan segera setelah bayi lahir. ASI juga mempunyai banyak manfaat diantaranya dapat mempererat hubungan antara ibu dan bayi, dapat dijadikan sebagai alat kontrasepsi yang dikenal dengan istilah Metode Amenorea Laktasi (MAL).

Selama periode menyusui, ibu akan mengalami perubahan hormonal di dalam tubuhnya, yang semula estrogen dan progesteronnya tinggi, setelah melahirkan akan mengalami penurunan, ditambah lagi dengan adanya isapan bayi yang merangsang puting susu dan mengenai ujung-ujung saraf sensorif yang berfungsi sebagai reseptor mekanik. Rangsangan dilanjutkan ke hipotalamus yang akan menekan pengeluaran faktor-faktor yang menghambat prolaktin dan sebaliknya merangsang faktor-faktor yang mengacu prolaktin, kondisi ini akan mempengaruhi pada kembalinya menstruasi.

Pemberian ASI secara Eksklusif akan memperngaruhi waktu pertama kali menstruasi ibu menyusui. Ibu yang memberikan ASI secara langsung pada bayinya akan mengalami menstruasi lebih lama atau mengalami menstruasi normal kembali, hal ini dikarenakan penghisapan air susu oleh bayi menyebabkan terjadinya peningkatan hormon prolaktin. Prolaktin bukan hanya menyebabkan meningkatnya produksi ASI, tetapi juga mempengaruhi ovulasi / siklus menstruasi. Karena pada kenyataannya prolaktin $90 \%$ efektif mencegah terjadinya sekresi hormon yang diperlukan untuk ovulasi yaitu GnRH dan FSH/LH. Oleh karena itu, bila kadar prolaktin meningkat dalam darah, ovulasi tidak terjadi, selain itu prolaktin juga mempengaruhi siklus menstruasi.

Pada ibu yang tidak memberikan ASI secara eksklusif pada bayinya atau telah diberi suplemen dengan makanan pendamping ASI akan mengalami menstruasi lebih cepat. Keadaan ini disebabkan karena bayi tidak secara langsung menyusu pada ibunya yang menyebabkan menurunnya kadar prolaktin dimana diketahui bahwa prolaktin yang tinggi dihasilkan oleh karena adanya rangsangan pada daerah areola mamae ibu. Hal ini menyebabkan prolaktin tidak adekuat memblok hormon gonadotropin sehingga menyebabkan perkembangan folikel ovarium dan pembentukan hormon estrogen sehingga ibu akan mengalami menstruasi lebih cepat.

\section{KESIMPULAN}

1. Distribusi frekuensi Amenorea Laktasi di Wilayah Kerja UPTD Puskesmas Tanjung Agung Baturaja, dari 28 responden yang memberikan ASI Eksklusif pada bayinya, sebanyak 25 responden $(89,2 \%)$ yang merupakan MAL, sedangkan dari 24 responden yang 
tidak memberikan ASI Eksklusif pada bayinya hanya terdapat 2 responden $(8,3 \%)$ yang menjadi pengguna MAL.

2. Distribusi frekuensi pemberian ASI Eksklusif pada bayi di Wilayah Kerja UPTD Puskesmas Tanjung Agung Baturaja dengan kategori memberikan ASI Eksklusif berjumlah 28 responden $(53,8 \%)$ dan yang tidak memberikan ASI Eksklusif berjumlah 24 responden $(46,2 \%)$.

3. Distribusi frekuensi lamanya amenorea laktasi di Wilayah Kerja UPTD Puskesmas Tanjung Agung Baturaja pada ibu yang memberikan ASI Eksklusif ratarata mengalami amenorea sampai bayi berusia 7 bulan yaitu sebanyak 12 responden, sedangkan untuk ibu yang tidak memberikan ASI Eksklusif rata-rata sudah mendapatkan menstruasi kembali sejak bayi berusia 3 bulan.

4. Ada perbedaan yang signifikan (nyata) antara ibu yang memberikan ASI Eksklusif dan Non ASI Eksklusif terhadap Amenorea Laktasi di Wilayah Kerja UPTD Puskesmas Tanjung Agung Tahun 2019, dengan nilai Sig. (2-tailed) sebesar $0,000<0,05$.

\section{SARAN}

1. Bagi Dinas Kesehatan, Puskesmas, dan Lembaga Pengelola KB

Diharapakan hasil penelitian ini dapat digunakan sebagai bahan informasi mengenai adanya perbedaan antara ibu yang memberikan ASI Eksklusif dan Non Eksklusif terhadap Amenorea Laktasi, terkhusus di Wilayah Kerja UPTD Puskemas Tanjung Agung Baturaja, Sehingga dapat mensosialisasikan pemberian ASI Eksklusif sebagai salah satu alternatif kontrasepsi pasca persalinan sehingga nantinya akan dilaksanakan program kesehatan ibu dan anak yang bersinergi dengan program keluarga berencana.

2. Bagi Petugas Kesehatan

Diharapkan dapat digunakan bahan masukan bagi petugas kesehatan untuk meningkatkan perannya dalam memberikan konseling pada ibu melahirkan dan juga yang mempunyai bayi untuk tetap memberikan ASI secara Eksklusif pada 6 bulan pertama karena selain bermanfaat bagi kesehatan bayi juga memiliki keuntungan bagi ibu yaitu sebagai metode kontrasepsi alamiah.

3. Bagi Institusi

Diharapkan dapat digunakan sebagai referensi dan bahan kepustakaan untuk dapat meningkatkan kualitas pendidikan bagi mahasiswa khususnya Program Diploma IV Kebidanan Universitas Kader Bangsa Palembang dan mahasiswa kesehatan lain pada umumnya.

4. Bagi Peneliti Yang Akan Datang Diharapkan penelitian ini dapat dijadikan sebagai salah satu acuan bagi peneliti yang akan datang yang melakukan penelitian dengan variabel dan sampel yang berbeda sehingga penelitian ini dapat terus berkembang dan sebagai upaya untuk meningkatkan capaian pemberian ASI Eksklusif dan juga Metode Amenorea Laktasi (MAL).

5. Bagi Masyarakat

Diharapkan penelitian ini dapat nenambah wawasan tentang kontrasepsi Metode Amenore Laktasi (MAL), sehingga dapat memotivasi penggunaan ASI eksklusif sebagai salah satu pilihan metode kontrasepsi alamiah.

\section{DAFTAR PUSTAKA}

Birrulwalidaini. 2016.Pengaruh Pendidikan Kesehatan Tentang Metode Amenorea Laktasi Terhadap Pengetahuan Kontrasepsi Pada Ibu Primipara di Puskesmas Piyungan. Skripsi. Program StudiBidanPendidikJenjang Diploma IV Fakultas Ilmu Kesehatan. Universitas 'Aisyiyah. YogyakartaKemenkes RI. 2018. ProfilKesehatanIndonesia 2017. Jakarta: KemenkesRI.

Dinas Kesehatan Kabupaten OKU. 2018. Profil Kesehatan Kabupaten Ogan Komering Ulu 2018. Baturaja: Dinas Kesehatan Kabupaten OKU.

Malinda PD., Suprapti., dan Kusumawati E. 2013. Perbedaan Pengetahuan Ibu 
Hamil Trimester III Tentang Metode Amenorea Laktasi (MAL) Sebelum dan Sesudah Penyuluhan Di Puskesmas Bangetayu Kota Semarang. Semarang: Jurnal Unimus.

Nazriyanti D danRosida L. 2017.HubunganPemberian ASI EksklusifDenganMenstruasiPertama Kali PadaIbuMenyusuiDenganBayiUsia 6-11 Bulan Di Wilayah KerjaPuskesmasJetis Kota. Skripsi.Program StudiKebidanan Diploma IV. Universitas 'Aisyiyah.Yogyakarta.

Notoatmodjo. 2012. Metodologi Penelitian Kesehatan. Jakarta: Rineka Cipta.

Saifuddin,

2006.BukuPanduanPraktisPelayananK ontrasepsi. Jakarta: YayasanBinaPustakaSarwonoPrawiroha rdjo.

Saleha, Sitti. 2009. AsuhanKebidananPadaMasaNifas.

Jakarta: salembaMedika.

Suparmi. 2010. Pengaruh ASI

EksklusifterhadapAmenoreaLaktasi

Indonesia

Tesis.FakultasIlmuKesehatanMasyaraka t,Universitas Indonesia. Jakarta.

SusantoDH.,Cikutra RY., Nugraha A., Sasmita DM. 2017. Hubunganantara ASI

EksklusifdenganKejadianAmenorepadaI bu yang memilikiBayi di PuskesmasKelurahanPalmerah II. Jakarta: Universitas Kristen KridaWacana. 